\title{
Effects of water addition to total mixed ration on water intake, nutrient digestibility, wool cortisol and blood indices in Corriedale ewes
}

\author{
Jalil Ghassemi Nejad', Byong-Wan Kim', Bae-Hun Lee', Ji-Yung Kim', and Kyung-Il Sung 1,*
}

\section{* Corresponding Author: Kyung-II Sung Tel: +82-33-250-8635, Fax: +82-33-242-4540, \\ E-mail: kisung@kangwon.ac.kr}

'Department of Animal Resource Science, College of Animal Life Sciences, Kangwon National University, Chuncheon 24341, Korea

Submitted Jun 19, 2016; Revised Dec 1, 2016; Accepted Feb 4, 2017
Objective: The objective of this study was to determine the effect of adding water to total mixed ration (TMR) on fresh water intake, nutrient digestibility, wool cortisol, and blood indices in Corriedale ewes under hot and humid conditions.

Methods: Nine non-pregnant Corriedale ewes (ave. body weight $=41 \pm 3.5 \mathrm{~kg}$ ) were individually fed diets based on maintenance requirements in metabolic crates. Ewes were assigned to three treatment groups according to a triplicate $3 \times 3$ Latin Square design for 3 periods of 21 days duration each ( 9 ewes per treatment, 27 replications). Treatments were TMR (crude protein $[C P]=16.1$, total digestible nutrients $=69.1 \%$ ) moisture levels for $40 \%, 50 \%$, and $60 \%$.

Results: No differences were found in body weight gain among all treatment groups $(\mathrm{p}>0.05)$. Nitrogen balance including digestible $\mathrm{N}$, retained $\mathrm{N}$, and urinary and fecal $\mathrm{N}$ showed no change among the treatment groups ( $\mathrm{p}>0.05)$. Fresh water intake was the lower in 50\% TMR moisture group than in the other groups $(\mathrm{p}<0.05)$. Other than ether extract which was higher in $60 \%$ TMR moisture group $(\mathrm{p}<0.05)$ the differences among nutrient digestibilities including $\mathrm{CP}$, organic matter, dry matter, neutral detergent fiber, acid detergent fiber, and non-fiber carbohydrate were not significant $(\mathrm{p}>0.05)$. No significant difference was observed for serum protein, blood urea nitrogen, glucose, and triglyceride among the treatment groups ( $>00.05)$. Wool and blood cortisol were not different among the treatment groups $(\mathrm{p}>0.05)$. Blood hematology including red blood cell, white blood cells, hemoglobin, hematocrit, basophils, and eosinophils were not different among the treatment groups $(\mathrm{p}>0.05)$.

Conclusion: It is concluded that TMR moisture at $40 \%, 50 \%$, and $60 \%$ had no effects on N balance parameters, and nutrient digestibilities except for the ether extract under hot and humid conditions. Additionally there were no effects on stress conditions include wool cortisol, as well as blood cortisol levels of ewes.

Keywords: Corriedale Ewes; Stress; Digestibility; Blood Parameters; Total Mixed Ration Moisture; Wool Cortisol

\section{INTRODUCTION}

Feed moisture may change the palatability and dry matter intake (DMI) of feed by the animals. Moreover, earlier studies $[1,2]$ have reported no changes in starch digestibility due to increasing levels of moisture in total mixed ration (TMR).

It was hypothesized that the palatability of the feed particles may decline due to adding water to TMR. While Fish and DeVries [3] observed that total neutral detergent fiber (NDF) and starch intake were not affected by water addition to the diets, in contrast, Miller-Cushon and DeVries [1] and Felton and DeVries [2] reported a reduction in total NDF and starch intakes corresponding to the decrease in DMI. Given that one of the three sources of water supply for the body is feed moisture [4], effects of different moisture content of TMR on nutrient intake, sorting be- 
havior, and production of dairy cows has been investigated [1-3,5]. They concluded that increasing TMR moisture by adding water decreases DMI and consequently other nutrient intake, increases the tendency of sorting against long particles in dairy heifers [6], and declines the production of dairy cows [2]. However, most often adding water to TMR results in a significant change in production due to a decline in $\mathrm{DMI}$ as the dry matter (DM) proportion of the TMR falls below $45 \%$.

It should be noted that feed moisture and drinking water is necessary for proper rumination and digestion [7-9], and nutrient digestibility can be improved in animals by decreasing feed intake under heat stress conditions $[10,11]$. Sheep require less water per unit of feed DM and have drier feces than cows do $[8,11]$. Adding water to feed is hypothesized to have compensation effects on fresh water intake that may influence the need for water supply to sheep.

The variation in climatic variables like temperature and humidity are recognized as potential hazards in the growth and production of all domestic livestock species. High ambient temperature accompanied by high air humidity caused an additional discomfort and enhanced the stress levels which in turn resulted in depression of the physiological and metabolic activities of the animal. Measuring the wool cortisol level with a new and accurate approach is a documented measurement to evaluate levels of chronic stress includes heat stress in sheep [7] and cows [12]. Furthermore, researchers [13-15] have reported that in a hot and humid climate, especially with heat stress, may alter serum biochemical parameters and hematology [15-17] in livestock due to capacity of the animals to adapt to the new environmental conditions. This and the possible effects of TMR moisture at different levels need to be investigated. Therefore, the effects of adding water to TMR on fresh water intake, nutrient digestibility, stress status in Corriedale ewes, especially during hot and humid conditions were evaluated.

\section{MATERIALS AND METHODS}

\section{Animals, treatments and experimental design}

The experimental procedure and methods were approved by The Animal Welfare and Ethics Authority of Kangwon National University, Chuncheon, Republic of Korea. Nine non-pregnant 3-yr old Corriedale ewes (ave. body weights $[\mathrm{BW}]=41 \pm 3.5 \mathrm{~kg}$ ) were individually fed diets (TMR; crude protein $[\mathrm{CP}]=16.1$, total digestible nutrients $[\mathrm{TDN}]=69.1 \%$ ) based on maintenance requirements [18] with an additional $10 \%$ to ensure that they fed at their maintenance levels. Ewes were kept in metabolic crates $(0.75 \mathrm{~m}$ $\times 1.45 \mathrm{~m}$ ) and were assigned to three different treatment groups according to a triplicate $3 \times 3$ Latin Square design for 3 periods of 21-d each ( 9 sheep per treatment). Treatments involved adding water to TMR in order to increase the moisture to $40 \%, 50 \%$, and $60 \%$. All ewes had ad-libitum access to water. Water was added to the TMR each time prior to feeding. The control group of TMR provided with $40 \%$ moisture. In order to increase the moisture to the TMR up to $50 \%$ and $60 \%$, the certain amount of water (calculated based on DM of the TMR) were added each time to each group. Then, after proper mix of added water to the TMR, feed was offered to each ewe.

Ewes were placed in individual metabolic crates with metal grated floors designed for urine and feces collection. Ewes were acclimated to the environment and experimental conditions for $10 \mathrm{~d}$ prior the experiment. At the beginning of each experimental period an adaptation period of 14-d was allotted in which ewes were allowed to adapt to the new treatment group to which they were assigned. The remaining 7 - $\mathrm{d}$ comprised a measurement period, the last of which blood was drawn. Lighting in the experimental house was maintained between 0800 and $2130 \mathrm{~h}$.

\section{Feed, water, wool sample, and urine and fecal collection} Feed was uniformed as a commercial TMR (Table 1) that was weighed and offered twice daily at $0900 \mathrm{~h}$ and $1800 \mathrm{~h}$. Ewes were fed at their maintenance levels [18] with an additional 10\% of their maintenance requirements throughout the experiment, so

Table 1. Ingredients and chemical composition of total mixed ration

\begin{tabular}{|c|c|}
\hline Item & $\% \mathrm{DM}$ \\
\hline \multicolumn{2}{|l|}{ Ingredients } \\
\hline Crushed corn & 4.0 \\
\hline Formula feed ${ }^{1)}$ & 5.0 \\
\hline Corn flake & 4.5 \\
\hline Wheat flake & 14.0 \\
\hline Wheat bran & 5.0 \\
\hline Corn gluten & 5.0 \\
\hline Sesame oil meal & 2.5 \\
\hline Brewer grain & 20.0 \\
\hline Liquid yeast & 17.2 \\
\hline Tall fescue & 6.2 \\
\hline Ryegrass & 7.5 \\
\hline Mixed hay ${ }^{2)}$ & 6.2 \\
\hline Molasses & 2.0 \\
\hline Vitamin-mineral premix & 0.9 \\
\hline \multicolumn{2}{|l|}{ Chemical composition } \\
\hline Dry matter & 60.0 \\
\hline Crude protein & 16.1 \\
\hline Crude fat & 4.4 \\
\hline Neutral detergent fiber & 40.0 \\
\hline Acid detergent fiber & 17.7 \\
\hline Ash & 6.6 \\
\hline Nitrogen free extract ${ }^{4)}$ & 55.4 \\
\hline Total digestible nutrients ${ }^{5)}$ & 69.1 \\
\hline \multicolumn{2}{|c|}{ 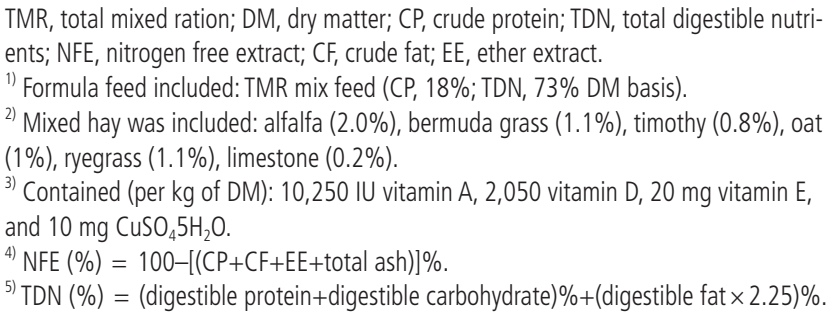 } \\
\hline
\end{tabular}


that no residual feed remained to weigh each day. The BW were measured on days 1,14 , and 21 of each period. Fresh water intake was recorded two times daily for the 5 final days of each period. Collections of urine and feces were performed daily for the final 7 days of each period, and were stored for analyses. Approximately $200 \mathrm{~g}$ of daily fecal excretion from each ewes were subsampled to a plastic bag, dried $\left(65^{\circ} \mathrm{C}\right.$ for 3 days), finely ground $(1 \mathrm{~mm})$ and analysed for nutrients including ether extract (method 920.39; [19]), and ash (method 927.02; [19]). The N (except for urine $\mathrm{N}$ ) was determined by Kjeldahl procedure using $\mathrm{Cu}^{2+}$ as a catalyst, and CP was calculated as $\mathrm{N} \times 6.25$ (method 984.13; [19]). Urinary $\mathrm{N}$ content was analysed as described by El Shazly [20]. Fibre content of feed and feces was determined using the method of Van Soest et al [21]. NDF and acid detergent fiber (ADF) were expressed with residual ash. Nitrogen free extracts (NFE) (Table 1) and non-fiber carbohydrate (NFC) (Table 3) were calculated using the formulas.

Preparing wool for cortisol analysis included shaving from the posterior vertex region of the neck between the cisterna magna and scapular bones, wrapping and unwrapping in aluminum foil, washing with isopropanol and methanol, drying, grinding, and then applying hair cortisol assay using the kit according to the manufacturers recommendation (Salimetrics, high sensitivity salivary cortisol, enzyme immuneassay kit, no. 1-3002, State College, PA, USA). Further details are described by Ghassemi Nejad et al [7]. The intra-assay and inter-assay coefficients of variations were 4.5 and 10.1, respectively.

Blood was collected by jugular venipuncture in two evacuated tubes at $1300 \mathrm{~h}$ on day 21 of each period. One sample (anticoagulant: ethylenediaminetetraacetic acid [EDTA], Greiner bio-one, New Orleans, LA, USA, reference no. 456073) was used to determine blood hematology characteristics, and the other (no additive: BD, Franklin Lakes, NJ, USA) was used to determine concentrations of serum protein, urea, glucose, and triglycerides (Modular analytic E170, Roche, Germany). After collection, serum was obtained by centrifugation $(1,200 \times \mathrm{g}$ for $20 \mathrm{~min})$ and then stored at $-20^{\circ} \mathrm{C}$ until analysis. Blood in vacutainers containing EDTA was used for blood hematology including red blood cells (RBC), white blood cells (WBC), hemoglobin, hematocrit, basophils, and eosinophils.

The diurnal temperature and humidity pattern as temperaturehumidity index (THI) in the experimental house are presented in Table 2 calculated as suggested by Marai et al [22].

\section{Statistical analysis}

The univariate procedure of SAS (version 9.1; SAS institute Inc., Cary, NC, USA) was used to check the normality of data. The result of this analysis showed that the data for all the measured characteristics were normally distributed. Statistical analysis was carried out using the general linear model procedure of SAS for a triplicate $3 \times 3$ Latin Square design. The model included effects of ewe, treatment, and period as follows:
Table 2. Average diurnal morning, noon and evening temperature and humidity pattern in the experimental house (0700 to 2000)

\begin{tabular}{lccc}
\hline Item & Hours & Values & SEM \\
\hline Temperature & $0700-0800$ & 28.7 & 0.1 \\
& $1200-1300$ & 32.3 & 0.2 \\
\multirow{3}{*}{ Relative humidity } & $1900-2000$ & 29.1 & 0.1 \\
& $0700-0800$ & 71.3 & 0.5 \\
& $1200-1300$ & 85.9 & 0.9 \\
THI $^{1)}$ & $1900-2000$ & 90.2 & 1.1 \\
& $0700-0800$ & 27.5 & - \\
& $1200-1300$ & 31.5 & - \\
\hline
\end{tabular}

SEM, standard error of the mean; $\mathrm{THI}$, temperature-humidity index.

${ }^{1)}$ Temperature-humidity index calculated as suggested by Marai et al [22].

$$
\mathrm{Y}_{\mathrm{ijkl}}=\mu+\alpha_{\mathrm{i}}+\mathrm{S}_{\mathrm{j}}+\mathrm{P}_{\mathrm{k}}+\varepsilon_{\mathrm{ijkl}}
$$

Where, $Y_{\mathrm{ijkl}}=$ each observation, $\mu=$ total mean, $\alpha_{\mathrm{i}}=$ effect of treatment, $\mathrm{S}_{\mathrm{j}}=$ effects of ewe, $\mathrm{P}_{\mathrm{k}}=$ effects of period, and $\varepsilon_{\mathrm{ikk}}=$ error. Experimental house environment was controlled throughout the experiment and the effects of ewe and period was not significant. Duncan multiple range test was used for ranking treatment means within a significant $\mathrm{F}$ test and statistical differences were considered significant at $\mathrm{p}<0.05$ and differences among means with $0.05<\mathrm{p}<0.10$ was accepted as representing tendencies to differences.

The THI data were averaged for weekly means (on hourly intervals) and analyzed by analysis of variance as repeated measures using the mixed procedure of SAS (version 9.1; SAS institute Inc., Cary, NC, USA). The covariance structures (autoregressive order 1 , unstructured and compound symmetry) for the repeated measures model were tested and the structure which fitted the model best was chosen based on the smallest Schwarts's Bayesian criterion.

\section{RESULTS}

\section{Nitrogen balance, feed intake, fresh water intake, and} nutrient digestibility

TMR moisture levels did not affect ( $\mathrm{p}>0.05) \mathrm{N}$ balance including $\mathrm{N}$ intake $(\mathrm{g} / \mathrm{d})$, fecal $\mathrm{N}(\mathrm{g} / \mathrm{d})$, digestible $\mathrm{N}(\mathrm{g} / \mathrm{d})$, urinary $\mathrm{N}(\mathrm{g} / \mathrm{d})$, retained $\mathrm{N}(\mathrm{g} / \mathrm{d})$, fecal $\mathrm{N} / \mathrm{N}$ intake (\%), urinary $\mathrm{N} / \mathrm{N}$ intake (\%), and retained N/N intake (\%) of the groups (Table 3). Feed intake remained unchanged $(p>0.05)$ during the experiment since animals were fed with an additional $10 \%$ of their maintenance level. The breakdown of which is as follows; $2.1 \mathrm{~kg}, 1.9 \mathrm{~kg}$ and $2.0 \mathrm{~kg}$ in $40 \%, 50 \%$, and $60 \%$ TMR moisture groups (as-fed prior to water addition to TMR), respectively. Body weight gains $(\mathrm{kg})$ in $40 \%, 50 \%$, and $60 \%$ TMR moisture groups were $1.0 \pm 0.1,1.1 \pm 0.5$, and $0.9 \pm 0.1 \mathrm{~kg}$, respectively. No differences were observed in BW of ewes among treatments $(\mathrm{p}>0.05)$. Fresh water intake $(\mathrm{L} / \mathrm{d})$ was lower $(\mathrm{p}=0.03)$ in the $50 \%$ TMR moisture group among the treatment groups, while no difference $(\mathrm{p}>0.05)$ was observed in 
Table 3. Effects of adding water to TMR on nitrogen balance in ewes during hot and humid conditions

\begin{tabular}{lccccc}
\hline \multirow{2}{*}{ Item } & \multicolumn{3}{c}{ TMR moisture } & \multirow{2}{*}{ SEM } & p-value \\
\cline { 2 - 4 } & $\mathbf{4 0 \%}$ & $\mathbf{5 0 \%}$ & $\mathbf{6 0 \%}$ & & \\
\hline Nitrogen balance & & & & & \\
$\quad$ N intake (g/d) & 17.5 & 17.5 & 17.5 & 0.15 & 0.55 \\
Fecal N (g/d) & 4.9 & 5.0 & 5.1 & 0.25 & 0.75 \\
Digestible N (g/d) & 13.8 & 13.7 & 13.7 & 0.27 & 0.57 \\
Urinary N (g/d) & 7.9 & 8.8 & 8.9 & 0.41 & 0.75 \\
Retained N (g/d) & 6.3 & 4.9 & 4.8 & 2.3 & 0.13 \\
Fecal N/N intake (\%) & 26.3 & 26.2 & 27.4 & 4.1 & 0.67 \\
Urinary N/N intake (\%) & 41.4 & 46.2 & 46.9 & 5.2 & 0.43 \\
Retained N/N intake (\%) & 33.2 & 27.1 & 25.7 & 4.5 & 0.35 \\
\hline
\end{tabular}

TMR, total mixed ration; SEM, standard error of the mean; DM, dry matter.

${ }^{1)}$ Treatments include: 40\% TMR, basal diet without water added; 50\% TMR, basal diet plus $10 \%$ water added (DM basis); $60 \%$ TMR, basal diet plus $20 \%$ water added (DM basis).

daily fresh water intake between the $40 \%$ and $60 \%$ TMR moisture groups (Table 4).

Ether extract digestibility showed a higher $(\mathrm{p}<0.05)$ value in the $60 \%$ TMR moisture group than other groups. However, digestibility of $\mathrm{CP}, \mathrm{ADF}, \mathrm{NDF}$, organic matter, NFE, and NFC were not different $(\mathrm{p}>0.05)$ among any of the treatment groups (Table 4$)$.

\section{Wool cortisol and blood parameters}

Wool cortisol concentrations ( $\mathrm{pg} / \mathrm{mg}$ of wool) were not different ( $>0.05$ ) among the treatment groups (Table 6). Serum biochemicals including protein $(\mathrm{g} / \mathrm{L})$, blood urea nitrogen $(\mathrm{BUN})(\mathrm{mmol} / \mathrm{L})$, glucose $(\mathrm{mmol} / \mathrm{L})$, and triglyceride $(\mathrm{mmol} / \mathrm{L}$ ) (Table 5$)$, and plasma hematology including RBC $\left(\times 10^{12} / \mathrm{L}\right)$, WBC $\left(\times 10^{9} / \mathrm{L}\right)$, hemoglobin $(\mathrm{g} / \mathrm{L})$, hematocrit, basophils $\left(\times 10^{9} / \mathrm{L}\right)$, and eosinophils $\left(\times 10^{9} / \mathrm{L}\right)$

Table 4. Effects of adding water to TMR on fresh water intake and nutrient digestibility in ewes during hot and humid conditions

\begin{tabular}{|c|c|c|c|c|c|}
\hline \multirow{2}{*}{ Item } & \multicolumn{3}{|c|}{ TMR moisture $^{1)}$} & \multirow{2}{*}{ SEM } & \multirow{2}{*}{ p-value } \\
\hline & $40 \%$ & $50 \%$ & $60 \%$ & & \\
\hline \multicolumn{6}{|l|}{ Fresh water intake } \\
\hline Average fresh water intake $(\mathrm{L} / \mathrm{d})$ & $4.1^{\mathrm{a}}$ & $3.6^{b}$ & $4.2^{\mathrm{a}}$ & 0.1 & 0.03 \\
\hline \multicolumn{6}{|l|}{ Digestibility of nutrients (\% DM) } \\
\hline Crude protein & 72.9 & 73.2 & 72.6 & 0.8 & 0.33 \\
\hline NDF & 51.9 & 53.5 & 52.0 & 1.7 & 0.15 \\
\hline ADF & 37.9 & 39.6 & 37.7 & 1.6 & 0.15 \\
\hline Ether extract & $84.9^{b}$ & $85.7^{b}$ & $89.5^{\mathrm{a}}$ & 1.1 & 0.03 \\
\hline $\mathrm{OM}$ & 70.5 & 71.3 & 70.2 & 1.6 & 0.27 \\
\hline Nitrogen free extracts & 75.6 & 76.3 & 75.1 & 1.2 & 0.23 \\
\hline Non-fiber carbohydrate ${ }^{2)}$ & 90.3 & 90.4 & 89.0 & 1.8 & 0.13 \\
\hline
\end{tabular}

TMR, total mixed ration; SEM, standard error of the mean; DM, dry matter; NDF, neutral detergent fiber; $A D F$, acid detergent fiber; $O M$, organic matter; $C P$, crude protein; $C F$, crude fat; NEF, nitrogen free extracts.

${ }^{1)}$ Treatments include: $40 \%$ TMR = basal diet without water added; 50\% TMR = basal diet plus 10\% water added (DM basis); $60 \%$ TMR = basal diet plus 20\% water added (DM basis).

${ }^{2)} \mathrm{NFC}(\%)=100-[($ Moisture $)-($ Ash $)-(\mathrm{CP})-(\mathrm{CF})-(\mathrm{NDF})] \%$.

${ }^{\text {ab }}$ Values within a row with different superscripts differ significantly at $p<0.05$. were not different $(\mathrm{p}>0.05)$ among the treatment groups (Table 6). Overall, wool cortisol and blood parameters remained unaffected by moisture levels of TMR.

\section{DISCUSSION}

Positive $\mathrm{N}$ retention with different TMR moisture in sheep may reflect recycling of $\mathrm{N}$ through the ruminal wall and saliva for microbial synthesis $[8,23]$. TMR in this study was controlled and had the same uniformed ingredients and chemical compositions. The only variable in the TMR was the DM, due to addition of water to TMR. It may change the palatability and DMI of feed by the animals. Several studies reported no changes in starch digestibility due to the addition of water to TMR $[1,2]$. They explained that the palatability of the feed particles may decline due to adding water to TMR. While Fish and DeVries [3] observed that total NDF and starch intake were not affected by water addition to the diets, in contrast, Miller-Cushon and DeVries [1] and Felton and DeVries [2] reported a reduction in total NDF and starch intakes corresponding to the decrease in DMI. These can all affect fiber digestibility which we have not found in the present study. This may be explained as due to feeding at the maintenance requirements which resulted in similar DMI and body weight gain. As ewes in the present study were fed diets based on their maintenance requirements it should have not led to a change in body weight and with different TMR moisture levels.

Higher moisture TMR is hypothesized to be associated with being more prone to spoilage due to increased temperature of the TMR during periods of increased environmental temperature $[24,25]$. Moreover, it could be hypothesized that higher moisture in the ration and higher THI would promote such spoilage. However, in the present study, ewes were fed based on maintenance requirements. Higher TMR moisture was not applicable to higher TMR temperature as the ewes finish eating within a few minutes of being offering the feed and thus there were no observed changes in DMI. Furthermore, moisture levels drive the extent of the fermentation and are associated with the starch digestion rate [2]. Over $50 \%$ of TMR moisture is reported to be related to more

Table 5. Effects of adding water to TMR on serum biochemicals in ewes during hot and humid conditions

\begin{tabular}{lccccc}
\hline \multirow{2}{*}{ Item } & \multicolumn{3}{c}{ TMR moisture $^{\text {1) }}$} & \multirow{2}{*}{ SEM } & p-value \\
\cline { 2 - 4 } & $\mathbf{4 0 \%}$ & $\mathbf{5 0 \%}$ & $\mathbf{6 0 \%}$ & & \\
\hline Protein (g/L) & 59.5 & 59.1 & 60.1 & 6.3 & 0.23 \\
BUN (mmol/L) & 4.5 & 4.7 & 4.6 & 0.5 & 0.35 \\
Glucose (mmol/L) & 3.0 & 3.1 & 2.9 & 0.3 & 0.23 \\
Triglyceride (mmol/L) & 0.3 & 0.3 & 0.2 & 0.1 & 0.27
\end{tabular}

TMR, total mixed ration; SEM, standard error of the mean; BUN, blood urea nitrogen; DM, dry matter.

1) Treatments include: 40\% TMR, basal diet without water added; 50\% TMR, basal diet plus 10\% water added (DM basis); $60 \%$ TMR, basal diet plus $20 \%$ water added (DM basis). 
Table 6. Effects of adding water to TMR on wool cortisol and hematologic characteristics in ewes during hot and humid conditions

\begin{tabular}{|c|c|c|c|c|c|}
\hline \multirow{2}{*}{ Item } & \multicolumn{3}{|c|}{ TMR moisture $^{1)}$} & \multirow{2}{*}{ SEM } & \multirow{2}{*}{$p$-value } \\
\hline & $40 \%$ & $50 \%$ & $60 \%$ & & \\
\hline Wool cortisol' (pg/mg of wool) & 2.2 & 2.1 & 2.3 & 0.1 & 0.13 \\
\hline \multicolumn{6}{|l|}{ Blood hematology } \\
\hline Red blood cell $\left(\times 10^{12} / \mathrm{L}\right)$ & 9.7 & 9.6 & 9.6 & 0.2 & 0.17 \\
\hline White blood cell $\left(\times 10^{9} / \mathrm{L}\right)$ & 5.5 & 5.9 & 6.0 & 0.5 & 0.23 \\
\hline Hemoglobin (g/L) & 89.8 & 87.3 & 89.4 & 1.6 & 0.17 \\
\hline Hematocrit & 0.3 & 0.3 & 0.3 & 0.1 & 0.35 \\
\hline Basophils $\left(\times 10^{9} / \mathrm{L}\right)$ & 0.1 & 0.2 & 0.1 & 0.1 & 0.17 \\
\hline Eosinophils $\left(\times 10^{9} / \mathrm{L}\right)$ & 0.2 & 0.2 & 0.1 & 0.1 & 0.23 \\
\hline
\end{tabular}

TMR, total mixed ration; SEM, standard error of the mean; DM, dry matter.

1) Treatments include: 40\% TMR, basal diet without water added; 50\% TMR, basal diet plus 10\% water added (DM basis); 60\% TMR, basal diet plus 20\% water added (DM basis).

${ }^{2)}$ All samples were derived from the same large pool of wool. Wool cortisol concentration represents the estimated concentration of cortisol in the wool shaft.

extensive degradation of protein, poor fermentation quality, and more extensive fermentation that results in high content of free acid and low $\mathrm{pH}$.

Digestibility of CP, ADF, and NDF were not different among the groups; however, higher ether extract digestibility of feed in $60 \% \mathrm{TMR}$ moisture was observed. In the present experiment the higher moisture may increase the rate of fat bypass to the small intestine which could result in higher ether extract digestibility. As such Miller-Cushon and DeVries [1] demonstrated that the addition of water to a high-moisture TMR will decrease feed sorting, and thus decrease the refusal of NDF, and will ultimately increase milk fat percentage and yield in lactating dairy cows that may be explained due to higher ether extract digestibility.

Buffers can aid in controlling rumen $\mathrm{pH}$. Sodium bicarbonate is the most widely used dietary buffer. Rations which benefit the most from buffers are rations which contain a high moisture level, and low fiber forages. Abnormally fermented material may alter the volatile fatty acid (VFA's) and lactic acid in the rumen [9]. Feed moisture is associated with saliva secretion. High moisture feeds can reduce saliva produced per kilogram of DMI by $50 \%$. It also may have compensation effects on fresh water intake of sheep. We hypothesized that an increase in TMR moisture may be associated with fresh water intake. In such a case, the reason(s) for lower fresh water intake in 50\% TMR moisture group than other groups and also similar fresh water intake in $40 \%$ and $60 \%$ TMR moisture group remains unknown. Ruminants have developed high water efficiency with improved utilization of body water resulting in the maintenance of DMI and performance [26]. It is commonly believed that addition of water to TMR will bind particles together and make it harder for the animals to sort out fine particles [1]. However, Leonardi et al [27] showed a reduction in the extent of feed sorting against long particles only when water was added to TMR up to $80 \%$ of DM. This and the fact that ewes in this study were fed based on maintenance requirements may explain why addition of water to TMR (maximum 60\%) had no extensive influence on fresh water intake and the related parameters. In addition, future investigations by feeding higher moisture
TMR for over $60 \%$ may improve our understanding of how possibly can affect fresh water intake.

More et al [13] reported a significant increase in the serum protein of sheep exposed to heat stress. The increase in serum protein could be a physiological attempt to maintain extended plasma volume. Glucose, BUN, and triglyceride may change due to high ambient temperature in camel $[14,15]$; however, the results of this investigation showed that adding water to TMR for $40 \%$ to $60 \%$ moisture has no significant influence on serum protein, BUN, glucose, triglyceride in ewes. These phenomena could be explained by the high potential of adaptability of the ewes in this study under the environmental conditions which is not influenced by the level of TMR moisture.

No differences in wool cortisol levels show that TMR moisture at $40 \%$ to $60 \%$ did not affect chronic stress in ewes under the experimental conditions. Ghassemi Nejad et al [12] found no difference in hair cortisol levels under heat stress conditions in lactating cows with different hair color (black vs white). In contrast Ghassemi Nejad et al [7] reported in elevated wool cortisol in ewes under similar environmental conditions but with water restrictions for $2 \mathrm{~h}$ and $3 \mathrm{~h}$ following feeding as treatment groups. In this study, concentrations of WBC remained constant among the treatment groups. Blood indices may change with stressors such as environment or temperature [28]. Decreases in hematocrit values during the hot season are partially due to a decrease in circulating erythrocytes. Other researchers [16,29] have verified a depression in hematocrit and erythrocytes in cattle subjected to elevated ambient temperatures and suggest that an increased rate of erythrocyte destruction may be responsible. In this study, $\mathrm{RBC}$ and hematocrit values remained unchanged among the treatment groups. No change in blood hematology parameters and biochemical with changes in TMR moisture from $40 \%$ to $60 \%$ revealed that TMR moisture potentially does not affect these parameters in particular.

\section{CONCLUSION}


This study aimed to investigate the effects of feeding different levels of TMR moisture for $40 \%$ to $60 \%$ during hot and humid conditions, regarding the fresh water intake, wool cortisol, blood indices, and nutrient digestibility of ewes. We found that TMR moisture is not linearly associated with fresh water intake. It was also observed that different levels of TMR moisture did not affect chronic stress conditions - wool cortisol, nutrient digestibility except ether extract of ewes under hot and humid conditions. We concluded that the moisture of the feed can apply from the range of $40 \%$ to $60 \%$ with no adverse effects on the welfare and nutrition of the ewes.

\section{CONFLICT OF INTEREST}

We certify that there is no conflict of interest with any financial organization regarding the material discussed in the manuscript.

\section{ACKNOWLEDGMENTS}

This study was supported by a grant from the Bio-industry Technology Development Program (313020-04), Ministry of Agriculture, Food, and Rural Affairs, Republic of Korea. The authors thank to Jennette B.A. Cabibi (Elmira College, SUNY University, USA) for her professional help in editing the manuscript.

\section{REFERENCES}

1.Miller-Cushon EK, DeVries TJ. Effect of dietary dry matter concentration on the sorting behavior of lactating dairy cows fed a total mixed ration. J Dairy Sci 2009;92:3292-8.

2.Felton CA, DeVries TJ. Effect of water addition to a total mixed ration on feed temperature, feed intake, sorting behavior, and milk production of dairy cows. J Dairy Sci 2010;93:2651-60.

3.Fish JA, DeVries TJ. Short communication: Varying dietary dry matter concentration through water addition: Effect on nutrient intake and sorting of dairy cows in late lactation. J Dairy Sci 2012;95:850-5.

4.Schoen A. Studies on the water balance of the East African goats. East Afr J Agric 1968;34:256-62.

5.Robinson PH, Burgess PL, McQueen RE. Influence of moisture content of mixed rations on feed intake and milk production of dairy cows. J Dairy Sci 1990;73:2916-21.

6.Khan MA, Bach A, Castells LI, et al. Effects of particle size and moisture levels in mixed rations on the feeding behavior of dairy heifers. Animal 2014;8:1722-7.

7.Ghassemi Nejad J, Lohakare JD, Son JK, et al. Wool cortisol is a better indicator of stress than blood cortisol in ewes exposed to heat stress and water restriction. Animal 2014;8:128-32.

8.Ghassemi Nejad J, Lohakare JD, West JW, et al. Effects of water restriction after feeding during heat stress on nutrient digestibility, nitrogen balance, blood profile and characteristics in Corriedale ewes. Anim Feed Sci Technol 2014;193:1-8.
9.Kaliber M, Koluman N, Silanikove N. Physiological and behavioral basis for the successful adaptation of goats to severe water restriction under hot environmental conditions. Animal 2015;10:82-8.

10. West JW. Effects of heat-stress on production in dairy cattle. J Dairy Sci 2003;86:2131-44.

11. Ghassemi Nejad J, Lohakare JD, West JW, et al. Effects of water restriction following feeding on nutrient digestibilities, milk yield and composition and blood hormones in lactating Holstein cows under heat stress conditions. Italian J Anim Sci 2015;14:479-83.

12. Ghassemi Nejad J, Kim BW, Lee BH, et al. Coat and hair color: hair cortisol and serotonin levels in lactating Holstein cows under heat stress conditions. Anim Sci J 2017;88:190-4.

13. More T, Singh M, Rai AK. Observation on excretory pattern of sodium, potassium and water at different temperature. Indian J Anim Sci 1980; 50:182-6.

14. Nazifi S, Gheisari HR, Poorabbas H. The influences of thermal stress on serum biochemical parameters of dromedary camels and their correlation with thyroid activity. Comp Haematol Int 1999;9:49-53.

15. Onasanya GO, Oke FO, Sanni TM, et al. Parameters influencing haematological, serum and bio-chemical references in livestock animals under different management systems. Open J Vet Med 2015;5:181-9.

16. Olbrich SE, Martz FA, Tumbleson ME, et al. Effects of constant environmental temperatures of $10^{\circ} \mathrm{C}$ and $31^{\circ} \mathrm{C}$ on serum biochemist and hematologic measurements of heat tolerant and cold tolerant cattle. Comp Biochem Physiol 1972;41:255-66.

17. Ganaie AH, Shanker G, Bumla NA, et al. Biochemical and physiological changes during thermal stress in Bovines. Vet Sci Technol 2013; $4: 1-6$.

18. NRC (National Research Council). Nutrient requirements of sheep, 6th edn. Subcommittee on sheep nutrition, committee on animal nutrition, board on agriculture. Washington, DC: National Academy Press; 1985.

19. AOAC (Association of Official Analytical Chemists). International. Official Methods of Analysis of the Association of Official Analytical Chemists International, 15th edn. Washington, DC: AOAC International; 1990.

20. El Shazly K. Studies on the nutritive value of some common Egyptian feeding stuffs. I. Nitrogen retention and ruminal ammonia curves. J Agric Sci Camb 1958;51:149-56.

21. Van Soest PJ, Robertson JB, Lewis BA. Methods for dietary fiber, neutral detergent fiber, and non-starch polysaccharides in relation to animal nutrition. J Dairy Sci 1991;74:3583-97.

22. Marai IFM, El-Darawany AA, Fadiel A, et al. Physiological traits as affected by heat stress in sheep-A review. Small Rumin Res 2007;71: 1-12.

23. Yagil R. The desert camel. Comparative physiological adaptation. Basel Switzerland: Karger; 1985.

24. Kung LJr, Sheperd AC, Smagala AM, et al. The effect of preservatives based on propionic acid on the fermentation and aerobic stability of corn silage and a total mixed ration. J Dairy Sci 1998;81:1322-30.

25. Eastridge ML. Major advances in applied dairy cattle nutrition. J Dairy Sci 2006;89:1311-23. 
26. Silanikove N. The struggle to maintain hydration and osmoregulation in animals experiencing severe dehydration and rapid rehydration: the story of ruminants. Exp Physiol 1994;79:281-300.

27. Leonardi C, Giannico F, Armentano LE. Effect of water addition on selective consumption (sorting) of dry diets by dairy cattle. J Dairy Sci 2005;88:1043-9.
28. Kalra S, Einarson A, Karaskov T, et al. The relationship between stress and hair cortisol in healthy pregnant women. Clin Invest Med 2007; 30:103-7.

29. Roussel JD, Patrick TEH, Beatty CJF, et al. Temperature effect of blood cells, enzymes, and protein activity of beef bulls. J Anim Sci 1970;30: 327-31. 